\title{
Spatio-Temporal Analysis of Soybean Root Colonization by Fusarium solani f. sp. glycines in Fields
}

\author{
Y. Luo, S. K. Chong, and O. Myers, Department of Plant, Soil and General Agriculture, Center for Excellence in \\ Soybean Research, Teaching and Outreach, Southern Illinois University, Carbondale 62901-4415
}

\begin{abstract}
Luo, Y., Chong, S. K., and Myers, O. 2001. Spatio-temporal analysis of soybean root colonization by Fusarium solani f. sp. glycines in fields. Plant Dis. 85:303-310.

Soybean roots were sequentially collected from two no-till fields from June 1997 through December 1998. Roots were ground to isolate and enumerate the fungus Fusarium solani f. sp. glycines, the causal agent of soybean sudden death syndrome (SDS), to obtain CFU per gram of root. The $\log \mathrm{CFU}\left[\log _{10}(\mathrm{CFU}+1)\right]$ versus sampling time was used to produce the pathogen population curve, and the area under the pathogen population curve (AUPC) was calculated for each plot. The average $\log$ CFU from all plots for each sampling date was used to fit the logistic equation. Plot data of $\log$ CFU at each sampling time of the growing season, AUPC, and foliar disease index (FDX) were correlated with each other. Correlations among the log CFU in root residue in the winter of 1997, the $\log$ CFU and FDX in the 1998 growing season were also conducted. Geostatistics was applied to determine the spatial dependence in root colonization for different lag distance in the fields using semiviograms. Spatio-temporal autocorrelations of root colonization were studied using a computer model STAUTO. During the growing season, pathogen population in roots followed logistic growth in both fields. Pathogen populations in root residue decreased during the winter of 1997 and increased slightly in the spring of 1998 prior to planting. AUPC significantly correlated with FDX in both fields in 1997. Pathogen populations in root residue at three sampling dates in the winter of 1997 significantly correlated $(r=0.47-0.53)$ with FDX of the 1998 growing season in one field. No spatial dependence in root colonization was detected early in the growing season. However, some spatial dependence in certain directions of the fields was detected later in the growing seasons. Spatial dependence in AUPC in the across-rows direction was detected in both fields in 2 years. Spatial lag orders 0 and 1 were significantly correlated with temporal lag order 1 in both within-row and across-row directions in field 1 in 1997.
\end{abstract}

Additional keywords: soilborne disease

Sudden death syndrome (SDS) of soybean (Glycine max (L.) Merrill), caused by Fusarium solani f. sp. glycines (19), is becoming an increasingly important disease in some soybean production areas in the United States $(19,20,22)$. Foliar symptoms of SDS usually appear slightly before or after reproductive stages given favorable field conditions for disease development (19). Pathogen population density in soil varies depending on time of soil sampling in relation to soybean growth stage (19) and was previously positively correlated with SDS foliar severity (23). Root colonization occurs prior to foliar symptom appearance $(3,11)$. Recent studies have revealed the dynamics of root colonization

Corresponding author: Yong Luo

E-mail: yluo@uckac.edu

Current address of Y. Luo: University of California, Davis, Kearney Agricultural Center, Parlier, CA 93648.

Accepted for publication 21 November 2000.

Publication no. D-2001-0112-01R

(C) 2001 The American Phytopathological Society under field conditions and the existence of differences in root colonization among cultivars (11). Correlations among root colonization, foliar disease index, and yield under certain field conditions were also determined (10). Data on the spatial distribution and temporal development of root colonization, as well as overwintering of the pathogen in root residue, provide important information to help understand mechanisms governing disease epidemics, pathogen infection cycles, the effect of notill practice on pathogen populations, and control of the disease using resistance.

Geostatistics is an important statistical tool $(7,8)$ that factors into account samplings at scales of field orientation, analyzes the relationship of disease development between neighboring or geographically related plots, and determines patterns of inoculum distribution. The semivariogram is used to determine spatial dependence by measuring the variation among samples with the similar distance $(7,8)$. Additionally, spatial analysis of disease distribution, combined with analysis of disease development in time, gives an overview of the entire disease development and helps us understand how spatial development of the disease changes with time.

Populations of $F$. solani $\mathrm{f}$. sp. glycines in soybean roots build throughout the growing season (10). The pathogen overwinters in soil and debris, and both chlamydospores and mycelia in roots serve as the primary inoculum source for root infection in the spring $(12,19)$. However, it is still not clear how pathogen populations in root residue change throughout the winters, nor how this change relates to both foliar and root disease development later in the growing season. Knowledge of the relationship among adjoining plots in root colonization is important in understanding of the mechanisms of primary infection and inoculum movements between plots in relation to foliar disease development. In this study, we determined the root colonization in both growing and winter seasons. The objectives of this study were to: (i) characterize the developments of root colonization by $F$. solani $\mathrm{f}$. sp. glycines in space and time using geostatistics, (ii) examine the correlations in root colonization between winter and growing seasons, (iii) determine pathogen population dynamics in relation to foliar disease development, and (iv) determine the spatiotemporal autocorrelations of root colonization.

\section{MATERIALS AND METHODS}

Experimental design. Experiments were conducted in two naturally infested fields at Southern Illinois University. The fields were no-tilled from 1996 to 1999 and were in corn-soybean rotation prior to 1996. Field 1 was $30 \times 65 \mathrm{~m}$ in 1997 and was enlarged to $30 \times 90 \mathrm{~m}$ in 1998 . Field 2 was $30 \times 30 \mathrm{~m}$ in 1997 and was enlarged to $30 \times 45 \mathrm{~m}$ in 1998 . The distance between the two fields was about $700 \mathrm{~m}$. The soybean cultivar Asgrow 5403 was planted in the two fields in both years. This cultivar is in maturity group 5.3, susceptible to SDS, and resistant to soybean cyst nematode races 3 and 14 . The soil in field 1 was identified as a Stoy silt loam (fine-silty, mixed, mesic Aquic Hapludalfs), and that in field 2 was a Weir silt loam (fine, smectitic, mesic Vertic Epiaqualfs) (6). Soybean was planted at a row spacing of $0.76 \mathrm{~m}$ and a density of 27 plants per meter of row in both fields. Planting dates were 16 May 1997 and 15 May 1998. Field 1 was divided into 40 plots in 1997 and 56 plots in 1998 , and each plot was $3.75 \times 13$ m with 
four rows. Field 2 was divided into 25 plots in 1997 and 40 plots in 1998, and each plot was $6 \times 6 \mathrm{~m}$ with eight rows. The two outer rows of each plot were used for destructive root sampling, and the two inner rows were used for foliar disease assessment.

Root sampling started in June 1997 and ended in December 1998 (through two growing seasons and a winter season). At each sampling date, three plants or three residual roots (in winter) were chosen at random in each plot. Root systems were removed from soil, lateral roots were pruned, and the three taproots were combined as one sample to be used for quantification of the pathogen population. Samples were taken six times during the 1997 growing season and four times during the 1998 growing season. The plants were harvested on 20 October 1997 and 11 October 1998. After harvest, residual roots were continuously sampled from the same plots throughout the winter of 1997 using the same method. Sampling dates and the corresponding soybean growth stages (2) are listed in Table 1.

Quantification of pathogen population from soybean roots. Taproots were washed thoroughly with water, surfacesterilized in $0.0525 \%$ sodium hypochlorite for $3 \mathrm{~min}$, rinsed three times with sterile distilled water, and dried in an incubator at $28^{\circ} \mathrm{C}$ for $24 \mathrm{~h}$ (for seedling roots) or $48 \mathrm{~h}$ (for adult roots). The three dried taproots from each plot were ground using a Wiley Mill (Thomas Scientific Inc., Swedesboro, NJ) to pass a 40-mesh screen. The mill and the screen tube were cleaned thoroughly between samples with a paintbrush and delicate task wipers to minimize contamination. Ground taproot tissue was weighed and then diluted with $200 \mathrm{ml}$ (for small taproots) or 2,000 $\mathrm{ml}$ (for large taproots) distilled water. A 1-ml root dilution of each sample was spread on a plate $(10 \times$ $150 \mathrm{~mm}$ ) containing $F$. solani f. sp. glycines selective medium $(11,13,21)$. Five plates were used for each root dilution. The plates were incubated at room temperature $\left(25 \pm 2^{\circ} \mathrm{C}\right)$ for 10 days. Colonies of $F$. solani $\mathrm{f}$. sp. glycines were identified as described previously $(10,11)$. The number of colonies on each plate was used to determine the CFU per gram of root for each sampling.

Foliar disease assessment. Foliar SDS assessed at growth stage R6 from three 1$\mathrm{m}$ sections of row randomly selected from the inner two rows in each plot. FDI was assessed as the percentage of plants showing symptoms, while FDS was assessed on a 0 to 9 scale based on the percentage of leaf area chlorotic, necrotic, or defoliated incidence (FDI) and severity (FDS) were

(3): $0=$ no detectable leaf symptoms; $1=1$ to $10 \%$ chlorotic or 1 to $5 \%$ necrotic; $2=$ 10 to $20 \%$ chlorotic or less than $10 \%$ necrotic; $3=20$ to $40 \%$ chlorotic or 10 to $20 \%$ necrotic; $4=40$ to $60 \%$ chlorotic or 20 to $40 \%$ necrotic; 5 = greater than $60 \%$ chlorotic or greater than $40 \%$ necrotic; $6=$ up to one-third premature defoliation; $7=$ one-third to two-thirds premature defoliation; $8=$ greater than two-thirds premature defoliation; and $9=$ plants prematurely dead. A foliar disease index (FDX) also
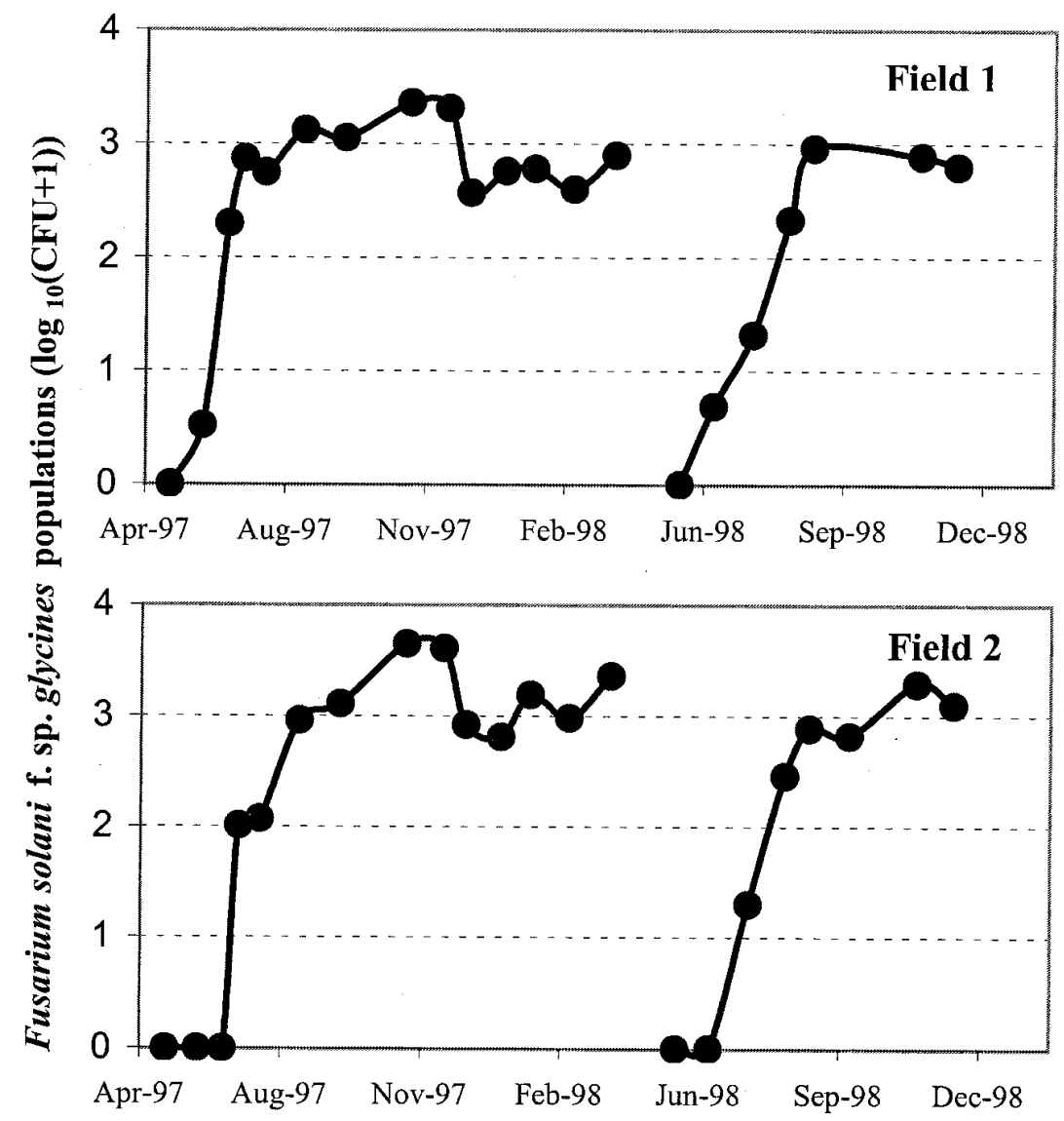

Month of the year

Fig. 1. Development of Fusarium solani f. sp. glycines populations in soybean roots. Experiments were conducted in two fields at Southern Illinois University, Carbondale. Soybean roots were sampled from June 1997 through December 1998. Each dot represents a mean of $\log \mathrm{CFU}\left(\log _{10}[\mathrm{CFU}+\right.$ $1)] / g$ root) from plots in fields.

Table 1. Dates of soybean root sampling from June 1997 through December 1998 and the corresponding soybean growth stages (4) on cultivar Asgrow 5403 for the two growing seasons ${ }^{\mathrm{a}}$

\begin{tabular}{|c|c|c|c|c|c|}
\hline \multirow{2}{*}{$\begin{array}{l}\text { Sampling order in } \\
\text { growing season }\end{array}$} & \multicolumn{2}{|c|}{1997} & \multirow{2}{*}{$\begin{array}{l}\text { Sampling order in } \\
\text { growing season }\end{array}$} & \multicolumn{2}{|c|}{1998} \\
\hline & Sampling date & Growth stage & & Sampling date & Growth stage \\
\hline 1 & 11 June & V3 & & 12 January & Root residue \\
\hline 2 & 28 June & V6 & & 2 February & Root residue \\
\hline 3 & 8 July & V8.5 & & $3 \mathrm{March}$ & Root residue \\
\hline 4 & 24 July & $\mathrm{R} 1$ & & 1 April & Root residue \\
\hline 5 & 21 August & R5.5 & 1 & 11 June & V3 \\
\hline \multirow[t]{5}{*}{6} & 19 September & $\mathrm{R} 8$ & 2 & 9 July & V8.5 \\
\hline & 5 November & Root residue & 3 & 4 August & $\mathrm{R} 2$ \\
\hline & 2 December & Root residue & 4 & 21 August & R5.5 \\
\hline & 18 December & Root residue & & 6 November & Root residue \\
\hline & & & & 12 December & Root residue \\
\hline
\end{tabular}

\footnotetext{
${ }^{a}$ Experiments were conducted in two fields at Southern Illinois University, Carbondale.
} 
was calculated as described by Gibson et al. (3) where FDX = FDI*FDS/9.

Data analysis. The CFU per gram of root for each sample was calculated by averaging five plates and then transformed using the formula: $\log _{10}(\mathrm{CFU}+1)$. The $\log$ CFU was plotted against sampling date of each growing season to produce a pathogen population curve for each plot. The area under the pathogen population curve (AUPC) was calculated for each plot using Euler's rectangular integration method (15).

The average log CFU from all plots for each sampling date per field was transformed by the logistic transformation: $\mathrm{Lc}=$ $\ln [c /(K-c)]$, where Lc is transformed $\mathrm{CFU}, c$ is the average log CFU, $K$ is the estimated maximum log CFU and obtained from the maximum log CFU of last sampling date from all experiments (two fields and 2 years). Linear regression of Lc on the days after planting was conducted using the REG procedure of SAS (version 7.0, SAS Institute, Cary, NC). The log CFU and FDX were classified into six levels for mapping the field distributions of root colonization and foliar disease index, respectively.

The individual data of $\log$ CFU, AUPC, and FDX were used to correlate with each other using the CORR procedure of SAS. The log CFU data sampled from the winter of 1997 through the spring of 1998 were also correlated with the log CFU and FDX data in the 1998 growing season for each field.
The software GS+ (version 3.1, Gamma Design Software, Plainwell, MI) was used to calculate the semivariances $\gamma(h)$, defined as the average of the squared difference in values between pairs of samples by a given distance $h$ (7). Variances of mean difference in $\log$ CFU, AUPC, and FDX between all plots for a given distance were applied. Semivariograms showing semivariance $\gamma(h)$ versus distance $h$ were determined for four directions, within rows, 45 degrees, across rows, and 135 degrees in the fields. The slope of an individual semivariogram was used to determine the existence of anisotropic spatial dependence $(7,8)$.

Spatio-temporal autocorrelations of soybean root colonization by $F$. solani $\mathrm{f}$. sp. glycines were analyzed using a computer model STAUTO (17). This model calculates the spatio-temporal autocorrelation between each spatial and temporal order. A field can be viewed as $N$ elements (quadrats), and the single element can be designated $i$. Suppose the disease was observed $T$ times on each element, then the disease observation at time $t$ in element $i$ can be designated $y_{i, t}$. For a given spatial lag $s$, STAUTO uses the following formula to calculate a spatial lag operator $L^{s} y_{i, t}$ :

$$
L^{s} y_{i, t}=\sum_{h \in j}\left(y_{h, t}\right) / n_{j}^{s}
$$

in which $j$ denotes the set of elements that lies at lag distance $s$ from element $i, n^{s}{ }_{j}$ denotes the number of elements in $j$ at lag $s$, and the notation $h \in j$ indicates that the summation is over all elements $h$ that belong to the set $j$ (17). The spatio-temporal autocorrelation coefficient was calculated for each spatio-temporal lag order. Thus, the autocorrelation matrix $R$ was produced by the model in which the elements of $R$ were calculated as:

$$
r_{h, j, s, k}=\frac{\sum_{t=v+1}^{T} \sum_{i=1}^{N}\left(L^{h} y_{i, t-j}-\hat{y}\right)\left(L^{s} y_{i, t-k}-\hat{y}\right)}{\sqrt{\sum_{t=v+1}^{T} \sum_{i=1}^{N}\left(L^{h} y_{i, t}-\hat{y}\right)^{2}} \sqrt{\sum_{t=v+1}^{T} \sum_{i=1}^{N}\left(L^{s} y_{i, t}-\hat{y}\right)^{2}}}
$$

where $r_{h, j, s, k}$ is the autocorrelation between spatial lag $h$ at time $j$ and spatial lag $s$ at time $k, L^{s}$ is the spatial lag operator defined above and $v=\max (j, k)$, and $\hat{y}$ is the grand spatio-temporal means, which is calculated as: $\hat{y}=\Sigma \Sigma y_{i, t} / N T$. The standardized $Z$ values were also calculated by the model that was used to determine the significance of spatio-temporal autocorrelations (17).

\section{RESULTS}

Development of root colonization during the growing and winter seasons. Root colonization started approximately at growth stage V3 and developed logistically throughout the growing seasons (Fig. 1). The root colonization at the last sampling date reached 1,120 (field 1) to 1,280 (field 2) CFU/g of root in September 1997, and 770 (field 2) to 910 (field 1) CFU/g of root in August 1998. Developments of pathogen populations in root residue were also similar in both fields. After the 1997 harvest (September), pathogen populations increased to 2,290 (field 1) to 4,460 (field

Table 2. Correlation coefficients showing the relationships among root colonization by Fusarium solani f. sp. glycines [ $\left.\log _{10}(\mathrm{CFU}+1)\right]$, the area under the

\begin{tabular}{|c|c|c|c|c|c|c|c|c|c|}
\hline \multicolumn{5}{|c|}{1997} & \multicolumn{5}{|c|}{1998} \\
\hline \multirow{2}{*}{$\begin{array}{l}\text { Root } \\
\text { sampling date }\end{array}$} & \multicolumn{2}{|c|}{ Field 1} & \multicolumn{2}{|c|}{ Field 2} & \multirow{2}{*}{$\begin{array}{c}\text { Root } \\
\text { sampling date }\end{array}$} & \multicolumn{2}{|c|}{ Field 1} & \multicolumn{2}{|c|}{ Field 2} \\
\hline & AUPC & FDX & AUPC & FDX & & AUPC & FDX & AUPC & FDX \\
\hline 11 June & 0.2363 & 0.0896 & $\ldots$ & $\ldots$ & 11 June & 0.1826 & 0.0647 & $0.4771 * * \mathrm{~b}$ & -0.0381 \\
\hline 28 June & $0.3998 * *$ & 0.0981 & $\ldots$ & $\ldots$ & 9 July & $0.5774 * * *$ & 0.0278 & $0.6225^{* * *} *$ & -0.0483 \\
\hline 8 July & 0.1786 & 0.0742 & 0.2361 & $0.6314 * *$ & 4 August & $0.5216^{* * * *}$ & 0.0912 & 0.1260 & $0.629 * * *$ \\
\hline 24 July & $0.4608 * *$ & 0.1145 & 0.3894 & -0.002 & 21 August & 0.1508 & $0.5332 * * *$ & $0.3612^{*}$ & -0.0330 \\
\hline 21 August & 0.1942 & $0.7315 * * *$ & $0.7512 * * *$ & 0.3626 & & & & & \\
\hline 19 September & $0.4018 * *$ & $0.6291 * * *$ & 0.4068 & 0.3642 & & & & & \\
\hline AUPC & & $0.3927 *$ & & $0.5813 * *$ & & & 0.2023 & & 0.1218 \\
\hline
\end{tabular}
pathogen population curve (AUPC), and foliar disease index (FDX) of soybean sudden death syndrome (SDS) ${ }^{\mathrm{a}}$

${ }^{a}$ Experiments were conducted in two fields at Southern Illinois University, Carbondale, in the 1997 and 1998 growing seasons. Each correlation was based on plot data in the fields.

$\mathrm{b} *, * *$, or $* * *=$ correlation was significant at $P \leq 0.05,0.01$, or 0.0001 , respectively.

Table 3. Correlation coefficients showing the relationships of soybean root colonization by Fusarium solani f. sp. glycines (log CFU) among root samples from the winter of 1997 through the spring of 1998, root samples during the 1998 growing season, and foliar soybean sudden death syndrome (SDS) dis-

\begin{tabular}{|c|c|c|c|c|c|}
\hline \multirow{2}{*}{$\begin{array}{l}\text { Root sampling date } \\
\text { in } 1997 \text { and } 1998\end{array}$} & \multicolumn{4}{|c|}{ Root sampling date in 1998} & \multirow[b]{2}{*}{ FDX } \\
\hline & 11 June & 9 July & 4 August & 21 August & \\
\hline 5 November 1997 & 0.0313 & 0.1284 & 0.1007 & $0.4186^{* * \mathrm{~b}}$ & $0.5282 * *$ \\
\hline 2 December 1997 & 0.0715 & 0.2817 & -0.1108 & 0.0839 & $0.4708 * *$ \\
\hline 18 December 1997 & -0.1579 & 0.1848 & 0.2291 & -0.0234 & 0.1263 \\
\hline 12 January 1998 & 0.0788 & 0.1146 & -0.0759 & $0.3681 *$ & $0.4779 * *$ \\
\hline 2 February 1998 & 0.1903 & 0.2396 & -0.1805 & 0.0012 & 0.3004 \\
\hline 3 March 1998 & -0.0190 & 0.0895 & 0.0368 & 0.0625 & 0.2389 \\
\hline 1 April 1998 & -0.1393 & -0.0959 & -0.0207 & -0.0626 & 0.0326 \\
\hline
\end{tabular}
ease index (FDX) throughout the 1998 growing season in field $1^{\text {a }}$

a Each correlation was based on individual plot data in the fields.

$\mathrm{b} *, * *$, or $* * *=$ correlation was significant at $P \leq 0.05,0.01$, or 0.0001 , respectively. 
1997
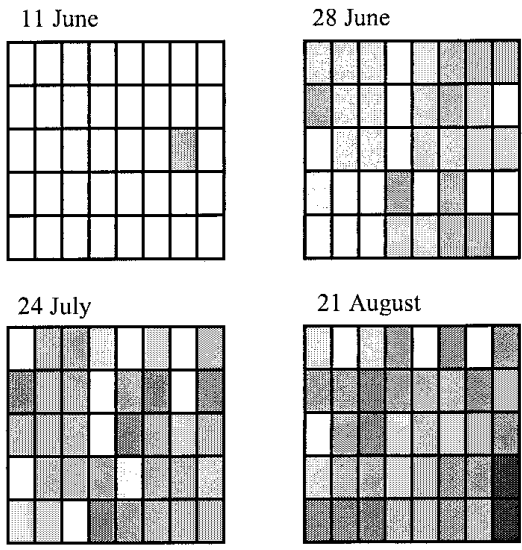

\section{8}

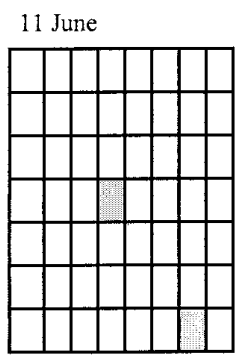

9 July
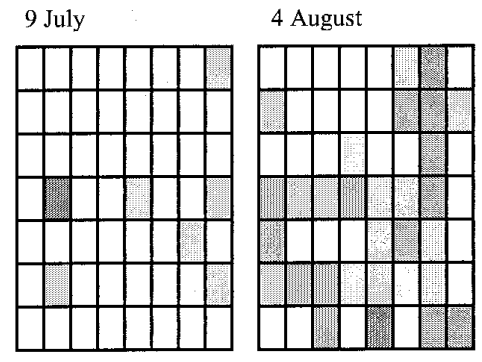

21 August

$\square<1.5$

$1.5-2.0$

2.0-2.5

2.1. 2.5-3.0

$3.0-3.5$

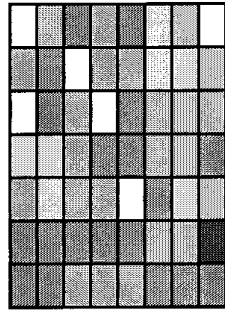

Fig. 2. Distribution of root colonization in log CFU by Fusarium solani f. sp. glycines in soybean field 1 for six sampling times during the 1997 growing season and four sampling times during the 1998 growing season. The field was extended from south in 1998. Each rectangle represents a plot of the field $(3.75$ by $12.86 \mathrm{~m})$ containing four rows, and roots were sampled from the two outer rows. Values for each plot were from three sampling roots.
2) $\mathrm{CFU} / \mathrm{g}$ of root until November, and decreased to approximately 370 (field 1 ) to 800 (field 2) CFU/g of root in December (Fig. 1). There was a slight change in population level from December 1997 through February 1998 (Fig. 1), and populations increased to 790 (field 1) to 2,290 (field 2) CFU/g of root in April 1998 prior to planting (Fig. 1). After harvest in 1998, although roots were sampled only two times in both fields, pathogen populations in root residue stayed at a higher level than those of last sampling in the growing season from November to December (Fig. 1).

Root colonization during the growing seasons fitted a logistic growth curve. The $P$ values of regression were $0.042\left(R^{2}=\right.$ $0.59)$ for field 1 and $0.015\left(R^{2}=0.72\right)$ for field 2 in 1997, and $0.027\left(R^{2}=0.75\right)$ for field 1 and $0.024\left(R^{2}=0.76\right)$ for field 2 in 1998.

Correlations among CFU, AUPC, and FDX. In the 1997 growing season, the log CFU of samplings on 28 June, 24 July, and 19 September in field 1 and the sampling on 21 August in field 2 significantly correlated with AUPC at either $P<0.01$ or $P$ $<0.0001$ based on individual plot data (Table 2). The $\log$ CFU of the samplings on 21 August and 19 September in field 1 and the sampling on 8 July in field 2 significantly correlated with FDX at either $P$ $<0.0001$ or $P<0.01$ (Table 2). In 1998, the $\log$ CFU of the samplings on 9 July and 4 August in field 1 and all samplings except that on 4 August in field 2 significantly correlated with AUPC at either $P$ <
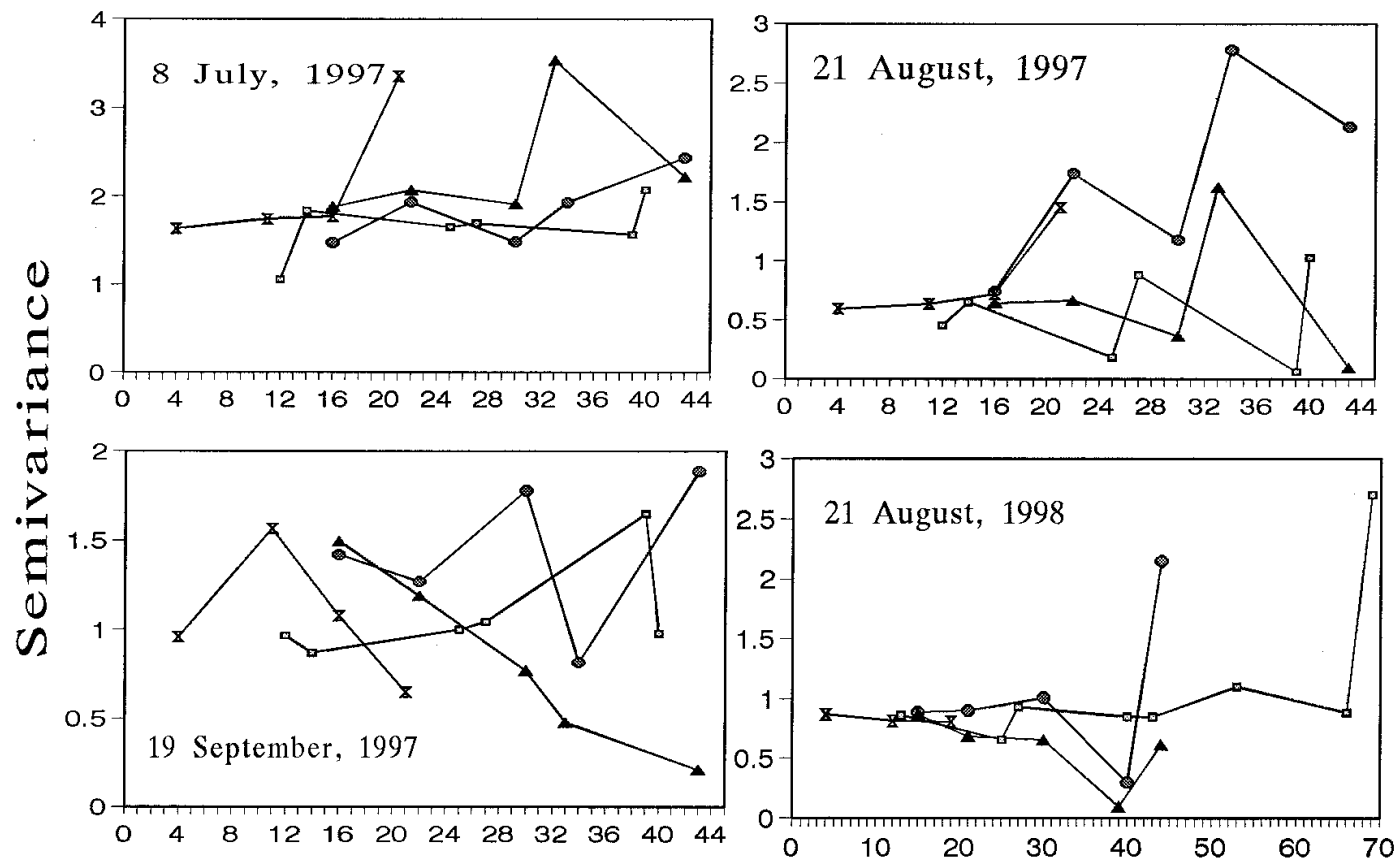

$\rightarrow$ Within rows $\$ 45$ degrees $\#$ Across rows 135 degrees

\section{Lag distance (m)}

Fig. 3. Semivariograms of soybean root colonization (log CFU) by Fusarium solani f. sp. glycines in field 1 for some sampling dates in the 1997 and 1998 growing seasons showing significant spatial dependence in some directions. 
$0.05, P<0.01$, or $P<0.0001$ (Table 2). The $\log$ CFU of the sampling on 21 August in field 1 and the sampling on 4 August in field 2 significantly correlated with FDX at $P<0.0001$ (Table 2). In 1997, AUPC significantly correlated with FDX in field 1 at $P<0.05$ and in field 2 at $P<0.01$ (Table 2). However, such correlation was not detected in either field in 1998 (Table 2).

In field 1, the $\log \mathrm{CFU}$ in root residue at the samplings on 5 November, 2 December 1997, and 12 January 1998 significantly correlated with FDX of the 1998 growing season (Table 3). The log CFU at the samplings on 5 November 1997 and 12 January 1998 significantly correlated with the sampling on 21 August 1998 (Table 3). However, no correlation was found in field 2 except for that between the sampling on 12 January 1998 and the sampling on 11 June 1998 (data not shown).

Spatial development of root colonization. In field 1, root colonization was depling of 1997 (Fig. 2). However, root colonization developed throughout the growing season, and there were some plots that showed colonization level greater than $3,100 \mathrm{CFU} / \mathrm{g}$ of root $(\log \mathrm{CFU}>3.5)$ at the last sampling (Fig. 2). Root colonization development in 1998 was similar to that in 1997, and only one plot showed colonization level greater than 3,100 CFU/g of root at the last sampling (Fig. 2). Spatial autocorrelograms showed no spatial dependence detected in this field at the samplings on 11 and 28 June 1997. However, at the samplings on 8 July and 21 August, spatial rows direction (Fig. 3). At the sampling on 19 September, spatial dependence was detected in the 45-degree direction, showing a decrease in semivariance with in1998, a spatial dependence was detected only in the across-rows direction at the last sampling on 21 August (Fig. 3). tected from only one plot at the first samdependence was observed in the acrosscreasing lag distance (Fig. 3). However, in
1997
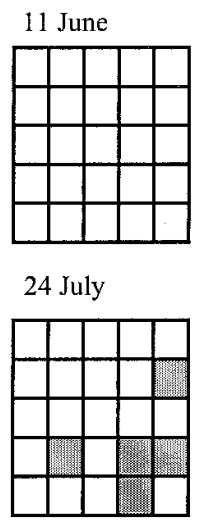

1998
11 June

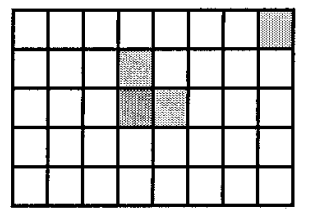

4 August

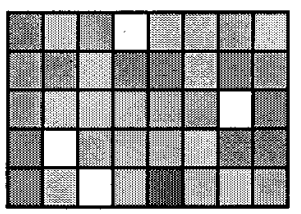

28 June

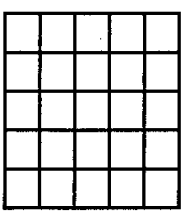

21 August

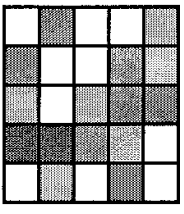

8 July

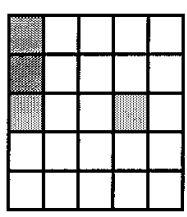

19 September

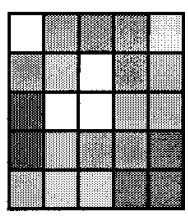

9 July

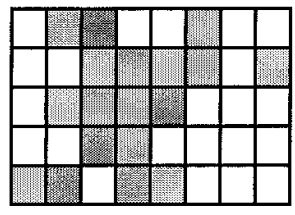

21 August

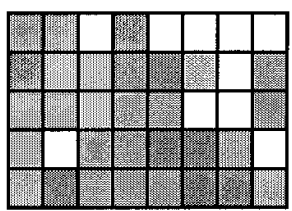

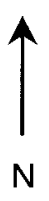

$\mathrm{N}$
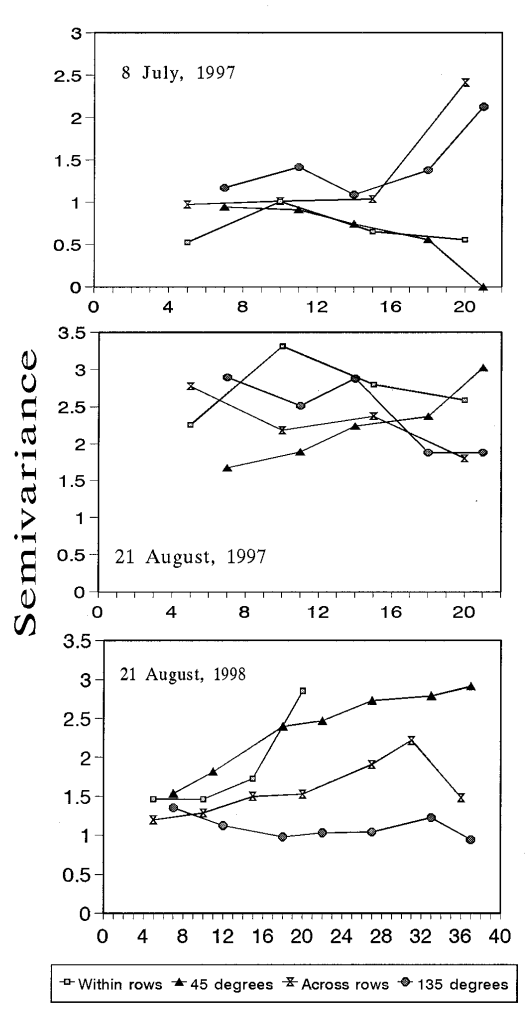

Lag distance (m)

Fig. 5. Semivariograms of soybean root colonifield 1 for some sampling dates in the1997 and 1998 growing seasons showing significant spatial dependence in some directions.

Spatial dependence in AUPC was detected in the across-rows direction in the with fields and the 2 years, showing that ances decreased in 1997 while increasing in 1998 (Fig. 6). Spatial dependence was

\section{.} zation by Fusarium solani f. sp. glycines in
Fig. 4. Distribution of root colonization in log CFU by Fusarium solani f. sp. glycines in soybean field 2 for six sampling times during the 1997 growing season and four sampling times during the 1998 growing season. The field was extended from east in 1998. Each square represents a plot of the field $(6$ by $6 \mathrm{~m}$ ). Each plot contained eight rows, and roots were collected from the two outer rows. Values for each plot were from three sampling roots.
A slightly different situation was observed in field 2. In 1997, root colonization was not detected until 8 July. At the last sampling (19 September), there were three foci showing a high colonization level (Fig. 4). In the early season of 1998, root 1997 (Fig. 4), and root colonization was distributed more widely than that observed in 1997 (Fig. 4). However, at the last sampling, no colonization greater than 3,100 CFU/g of root was detected (Fig. 4). Along with an increase in lag distance at the samcolonization increased in the across-rows direction and decreased in the 45-degree direction (Fig. 5). Semivariance increased as lag distance increased in the 45-degree direction at the sampling on 21 August was detected in any direction at the samplings on 24 July and 19 September. In 1998, spatial dependence was detected at the last sampling (21 August) that the semivariances increased along with lag distance in the within-rows and the 45degree directions (Fig. 5).

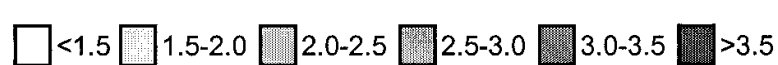

Plant Disease / March 2001 
also detected in the 45-degree direction of field 1 and in the within-rows direction of field 2 in 1997 (Fig. 6).

Spatial distribution of foliar disease. In field 1, two east plots in 1997 and one south plot in 1998 showed a foliar disease index greater than 50. Most plots showed low to moderate disease intensity (FDX = 10 to 40 ) (Fig. 7). In field 2, foliar disease was more severe in 1998 than in 1997. Proportions of plots showing FDX greater than 50 were $8 \%$ in 1997 and $15 \%$ in 1998 (Fig. 7). In 1997, the semivariances in FDX increased as increasing lag distance in the across-rows direction for field 1 and field 2 (Fig. 8). The semivariance also decreased with increasing lag distance in the within-rows direction of field 2 (Fig. 8). However, no spatial dependence was detected in two fields in 1998.

Spatio-temporal autocorrelations. Results by using STAUTO demonstrated that the temporal lag order 1 significantly correlated with spatial lag orders 0 and 1 in both within-rows and across-rows directions in field 1 in 1997 (Table 4). Negative autocorrelations between temporal lag order 4 and most spatial lag orders in this field in 1997 and between temporal lag orders 2 and 3 and most spatial lag orders in 1998 were also observed (Table 4). No other significance in spatio-temporal auto- correlation was found in field 2 in both years.

\section{DISCUSSION}

$F$. solani f. sp. glycines was detected in soybean roots approximately at growth stage V3 or later depending on the environment. Development of root colonization in the fields showed logistic growth throughout both growing seasons. At the end of the growing season, pathogen populations reached the highest level (about 1,500 CFU/g of root as an average). Under field conditions in southern Illinois, pathogen populations in root residue maintained a moderate level from October through December, subsequently decreased, and then maintained a lower level throughout the winter. Following in early spring, pathogen populations increased. In general, pathogen populations in root residue were present at a high level (300 to $1,500 \mathrm{CFU} / \mathrm{g}$ of root). Pathogen populations could continuously accumulate in soybean roots during the growing season.

Root colonization at certain growth stages significantly correlated with foliar disease index (FDX). We also observed that AUPC significantly correlated with FDX in 1997 but not in 1998. Because AUPC reflects the whole process of root colonization, the difference in onset of root colonization between 2 years may be one of the causes of the variation. For instance, root colonization was first detected 20 days later in 1997 than in 1998. According to the records from a weather station of Illinois Climate Network located in Carbondale, which was about $300 \mathrm{~m}$ from the two fields, average monthly air and soil temperatures in June 1998 were 2.1 and $1.1^{\circ} \mathrm{C}$ higher than in 1997, respectively. However, air and soil temperatures in July and August between 2 years were closed. The difference in weather may cause variation in onset of root colonization reflected by AUPC between 2 years.

Correlations in CFU among sampling dates in the winter of 1997, that of the growing season of 1998, and FDX of 1998 were significant in field 1 but not in field 2. This demonstrated that pathogen populations in root residue at least partially contributed to root infection and foliar disease development in the following growing season. Variation between the two fields implies that this correlation could be affected by field environment. For example, difference in soil type between the two fields may be one cause.

Semivariograms showed that the distribution of root colonization was more spatially dependent later in the season than early in the season, because random patterns of root colonization were detected at
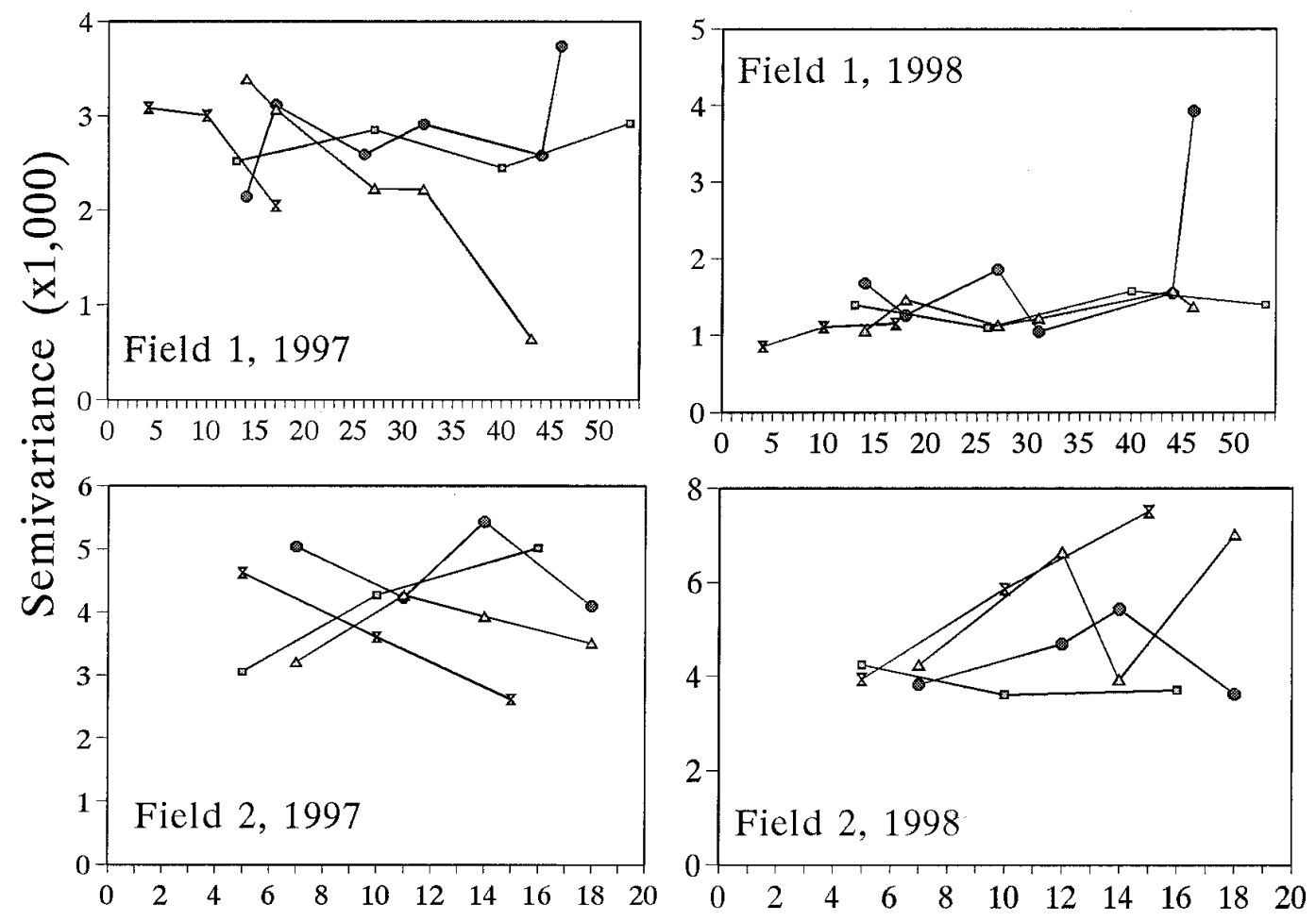

$\rightarrow$ Within rows $₫ 45$ degrees $Z$ Across rows 135 degrees

\section{Lag distance $(\mathrm{m})$}

Fig. 6. Semivariograms of the area under the pathogen population curve (AUPC) of root colonization by Fusarium solani f. sp. glycines in four directions of two fields in 2 years. 
the earlier time points, and clusters and foci of root colonization existed at later time points throughout the growing season. Even spatial dependence was not detected in some sampling dates, it is clear that the dynamic process of root colonization represented by AUPC is consistently spatially dependent in the across-rows direction in both fields and both years.

Spatio-temporal analysis showed that developments of root colonization were correlated between two sequential sampling dates only in short spatial lag distance (plot itself and neighboring plots) in some direction of the field. Therefore, pathogen dynamics in roots performed a short-distance dispersal and only the root colonizations between two sequential samplings were related.

Unlike earlier studies which had used spatial analysis for pathogen dispersal in the air $(4,5,18,24)$ and soil $(1,9,16,26,27)$, the present study emphasized the temporal and spatial developments of root colonization throughout the growing and winter seasons. A similar example was a study on Fusarium crown and root rot of tomato caused by Fusarium oxysporum f. sp. radicis-lycopersici (16). Using spatialtemporal analysis, Rekah et al. (16) concluded that roots were essential for the pathogen's movement in the soil. They demonstrated that two mechanisms might be involved in pathogen spread from one
1997

Field 1

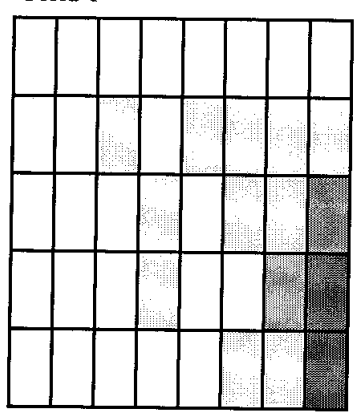

1998

Field 1
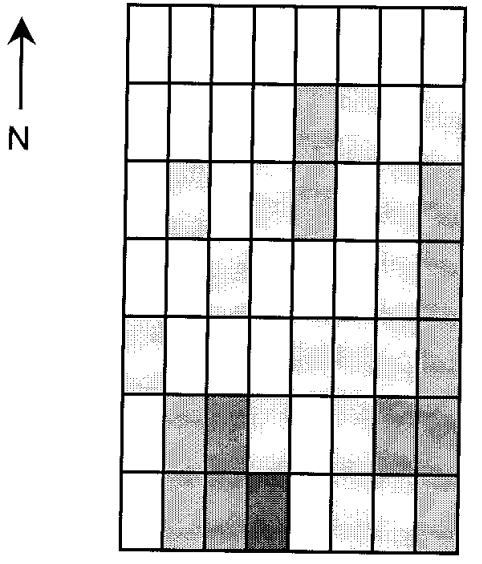

Field 2

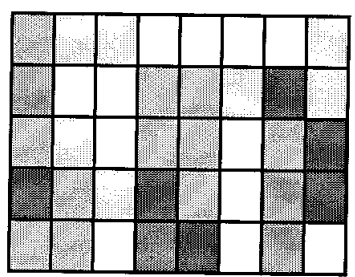

$31-40$

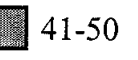

$0-10 \square 11-20 \square 21-30$
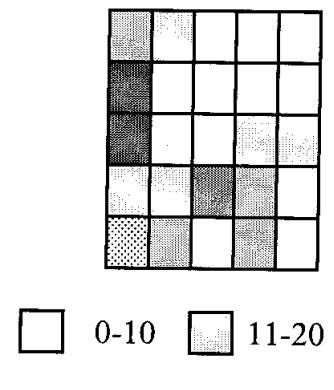

Fig. 7. Spatial patterns of foliar disease index (FDX) of soybean sudden death syndrome (SDS) in two fields and 2 years. Disease was assessed from the two inner rows in each plot at growth stage R6.

plant to another: mycelial growth through the soil toward the root and growth of the pathogen and its spread from root to root. This study also showed that pathogen populations of $F$. solani f. sp. glycines could accumulate in soybean roots. Pathogen spread may also relate to soil environments such as soil type, humidity, and water movement. Although the correlations among pathogen populations in root residue, root colonization in the growing season, and FDI were found in one field, and the dynamics of root colonization was found to be a short-distance dispersal, further extensive work is needed to determine the mechanism of pathogen dispersal in soil. Nevertheless, F. solani f. sp. glycines was not isolated from soil early in the season, and our plot data from soil samplings at midseasons (R3) showed a relatively low density of the pathogen (less than 100 $\mathrm{CFU} / \mathrm{g}$ of soil; data not presented). Therefore, pathogen movement in soil relates to many factors, including soil environments, pathogen life cycle in both soil and roots, and complex interactions. Compared with soil, plant roots are regarded as a better environment for pathogen growth due to

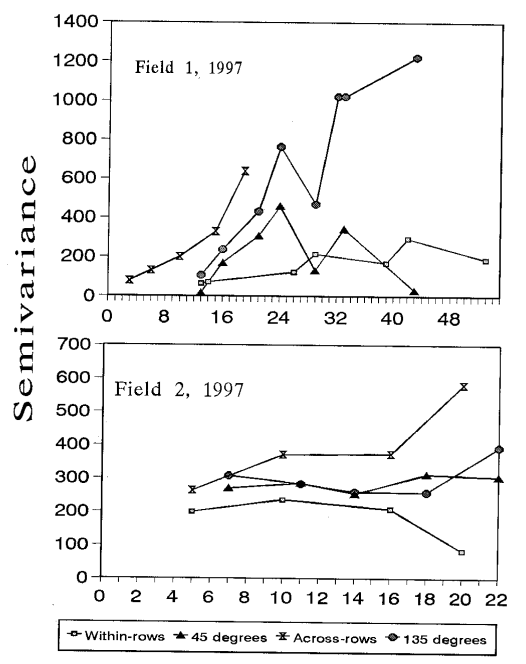

Lag distance $(\mathrm{m})$

Fig. 8. Semivariograms of foliar disease index (FDX) of soybean sudden death syndrome (SDS) in four directions of field 1 in 2 years.

Table 4. Spatio-temporal autocorrelation coefficients in soybean root colonization by Fusarium solani f. sp. glycines in log CFU in the within-rows and across-rows directions of field 1 in 1997 and $1998^{\mathrm{a}}$

\begin{tabular}{|c|c|c|c|c|c|c|c|c|c|c|}
\hline \multirow{2}{*}{$\begin{array}{l}\text { Temporal } \\
\text { lag order }\end{array}$} & \multicolumn{5}{|c|}{ Spatial lag order (within-rows) } & \multicolumn{5}{|c|}{ Spatial lag order (across-rows) } \\
\hline & $\mathbf{0}$ & 1 & 2 & 3 & 4 & $\mathbf{0}$ & 1 & 2 & 3 & 4 \\
\hline \multicolumn{11}{|l|}{1997} \\
\hline 1 & $0.42^{*}$ & $0.43^{*}$ & 0.31 & 0.31 & 0.21 & $0.42^{*}$ & 0.32 & 0.33 & 0.34 & 0.29 \\
\hline 2 & 0.16 & 0.16 & 0.17 & 0.05 & 0.06 & 0.16 & 0.06 & 0.17 & 0.16 & 0.13 \\
\hline 3 & -0.12 & -0.15 & -0.07 & 0.04 & 0.18 & -0.12 & -0.18 & 0.04 & -0.06 & -0.05 \\
\hline 4 & $-0.40 *$ & $-0.43 *$ & $-0.45^{*}$ & $-0.42 *$ & -0.21 & $-0.40 *$ & $-0.53 *$ & $-0.42 *$ & $-0.49 *$ & $-0.43 *$ \\
\hline \multicolumn{11}{|l|}{1998} \\
\hline 1 & 0.22 & 0.18 & 0.29 & 0.34 & 0.09 & 0.22 & 0.40 & 0.32 & 0.28 & 0.21 \\
\hline 2 & $-0.60^{*}$ & $-0.56^{*}$ & -0.50 & -0.50 & $-0.57^{*}$ & $-0.60 *$ & $-0.58 *$ & $-0.66^{*}$ & $-0.62 *$ & $-0.54^{*}$ \\
\hline 3 & $-0.82 * *$ & $-0.81 * *$ & $-0.79 * *$ & $-0.79 * *$ & $-0.68^{*}$ & $-0.82 * *$ & $-0.81^{* *}$ & $-0.74 *$ & $-0.80 * *$ & $-0.76^{*}$ \\
\hline
\end{tabular}

${ }^{a}$ Binary distance weighting was used. Values followed by * or ** indicate that autocorrelation was significant at $P \leq 0.05$ or $P \leq 0.01$, respectively. 
protection from the activity of antagonistic soil microorganisms. This may partially explain why pathogen accumulation was more rapid and pathogen density was higher in roots than in adjacent soil, especially earlier in the growing season.

Previous studies $(14,25)$ determined that SDS was more severe in no-till fields than in the fields with a proper tillage program. Although many works need to be done to understand pathogen survival and dynamics in both roots and soil, a practical finding emerges from this study, namely that accelerated decay or removal of root residue may help in disease control.

\section{ACKNOWLEDGMENTS}

This research was supported by the Illinois Council for Food and Agricultural Research (CFAR) grant no: 97I-02. We thank Laurence Madden for providing us with the STAUTO model with instructions and for a discussion on the results. We thank Jim Klein for his excellent field services. The comments from Eric Boehm, University of California, Kearney Agricultural Center, on this manuscript were gratefully appreciated.

\section{LITERATURE CITED}

1. Campbell, C. L., and van der Gaag, D. J. 1993. Temporal and spatial dynamics of microsclerotia of Macrophomina phaseolina in three fields in North Carolina over four to five years. Phytopathology 83:1434-1440.

2. Fehr, W. R., Caviness, C. E., Burmood, D. T., and Pennington, J. S. 1971. Stage of development descriptions for soybeans, Glycine $\max ($ L.) Merrill. Crop Sci. 2:929-931.

3. Gibson, P. T., Shenaut, M. A., Njiti, V. J., Suttner, R. J., and Myers, O., Jr. 1994. Soybean varietal response to sudden death syndrome. Pages 20-40 in: Proc. Soybean Seed Res. Conf., 24th. D. Wilkinson, ed. Am. Seed Trade Assoc., Washington, DC.

4. Gottwald, T. R., Reynolds, K. M., Campbell, C. L., and Timmer, L. W. 1992. Spatial and spatiotemporal autocorrelation analysis of citrus canker epidemics in citrus nurseries and groves in Argentina. Phytopathology 82:843851 .

5. Headrick, J. M., and Pataky, J. K. 1988. Spa- tial and temporal development of common rust in susceptible and partially resistant sweet corn hybrids. Phytopathology 78:227233.

6. Herman, R. J., Miles, C. C., Dungan, L. A., Currie, B. E., and Ice, P. W. 1979. Soil survey of Jackson County Illinois. Ill. Agric. Exp. Stn. Soil Rep. 106. University of Illinois at Urbana-Champaign College of Agriculture, Agriculture Experiment Station, in cooperation with SCS, USDA.

7. Issaks, E. H., and Srivastava, R. M. 1989. Applied Geostatistics. Oxford University Press, New York.

8. Journel, A. G., and Huijbregts, C. H. 1978. Mining Geostatistics. Academic Press, New York.

9. Larkin, R. P., Gumpertz, M. L., and Ristaino, J. B. 1995. Geostatistical analysis of Phytophthora epidemic development in commercial bell pepper fields. Phytopathology 85:191-203.

10. Luo, Y., Hildebrand, K., Chong, S. K., Myers, O., and Russin, J. S. 2000. Soybean yield loss to sudden death syndrome in relation to symptom expression and root colonization by Fusarium solani f. sp. glycines. Plant Dis. 84:914-920.

11. Luo, Y., Myers, O., Lightfoot, D. A., and Schmidt, M. E. 1999. Root colonization of soybean cultivars in the field by Fusarium solani f. sp. glycines. Plant Dis. 83:11551159.

12. Melgar, J., Roy, K. W., and Abney, T. S. 1994. Sudden death syndrome of soybean: Etiology, symptomatology, and effects of irrigation and Heterodera glycines on incidence and severity under field conditions. Can. J. Bot. 72:16471653.

13. Nash, S. M., and Snyder, W. C. 1962. Quantitative estimation by plate counts of propagules of the bean root rot Fusarium in field soils. Phytopathology 52:567-572.

14. Ploper, D. 1993. Sudden death syndrome: New soybean disease in northeastern Argentina. Agroindustrial Adv. Year 13. No. 54:5-9.

15. Rabbinge, R., Ward, S. A., and Van Laar, H. H. 1989. Simulation and Systems Management in Crop Protection. Center for Agricultural Publishing and Documentation (Pudoc) Wageningen.

16. Rekah, Y., Shtienberg, D., and Katan, J. 1999. Spatial distribution and temporal develop- ment of Fusarium crown and root rot of tomato and pathogen dissemination in field soil. Phytopathology 89:831-839.

17. Reynolds, K. M., and Madden, L. V. 1988 Analysis of epidemics using spatio-temporal autocorrelation. Phytopathology 78:240-246.

18. Reynolds, K. M., Madden, L. V., and Ellis, M A. 1988. Spatio-temporal analysis of epidemic development of leather rot of strawberry. Phytopathology 78:246-252.

19. Roy, K. W., Rupe, J. C., Hershman, D. E., and Abney, T. S. 1997. Sudden death syndrome of soybean. Plant Dis. 81:1100-1111.

20. Rupe, J. C. 1989. Frequency and pathogenicity of Fusarium solani recovered from soybeans with sudden death syndrome. Plant Dis. 73:581-584.

21. Rupe, J. C., Becton, C. M., Williams, K. J., and Yount, P. 1996. Isolation, identification, and evaluation of fungi for the control of sudden death syndrome of soybean. Can. J. Plant Pathol. 18:1-6.

22. Rupe, J. C., Hirrell, M. C., and Hershman, D. E. 1989. Sudden Death Syndrome. Pages 8485 in: Compendium of Soybean Disease. 3rd ed. J. B. Sinclair and P. A. Backman, eds American Phytopathological Society, St. Paul, MN.

23. Scherm, H., and Yang, X. B. 1996. Development of sudden death syndrome of soybean in relation to soil temperature and soil water matric potential. Phytopathology 86:642-649.

24. Stein, A., Kocks, C. G., Zadoks, J. C., Frinking, H. D., Ruissen, M. A., and Myers, D. E 1994. A geostatistical analysis of the spatiotemporal development of downy mildew epidemics in cabbage. Phytopathology 84:12271239.

25. Wrather, J. A., Kendig, S. R., Anand, S. C. Niblack, T. L., and Smith, G. S. 1995. Effects of tillage, cultivar, and planting date on percentage of soybean leaves with symptoms of sudden death syndrome. Plant Dis. 79:560 562.

26. Xiao, C. L., Hao, J. J., and Subbarao, K. V. 1997. Spatial patterns of microsclerotia of Verticillium dahliae in soil and Verticillium wilt of cauliflower. Phytopathology 87:325331.

27. Yang, X. B., Snow, J. P., and Berggren, G. T. 1991. Patterns of Rhizoctonia foliar blight on soybean and effect of aggregation on disease development. Phytopathology 81:287-293. 